\title{
Ammonium-bearing micas in very low-grade metapelites: micro- and nano-texture and composition
}

\author{
BLANCA BAULUZ ${ }^{1, *}$ AND FERNANDO NIETO ${ }^{2}$ \\ IUCA-Facultad de Ciencias, Universidad de Zaragoza, Spain \\ ${ }^{2}$ Departamento de Mineralogía y Petrología and IACT, Universidad de Granada-CSIC, Spain
}

(Received 15 November 2017; revised 5 April 2018; Guest Associate Editor: Sebastien Potel)

\begin{abstract}
ABS TRACT: The present study examines the micro- and nano-texture and composition of ammoniumbearing and potassium micas in very-low grade metamorphic black Silurian shales from the SE Iberian Range (NE Spain). Two organic-rich shales were studied by X-ray diffraction (XRD), infrared spectroscopy (IR), transmission electron microscopy (TEM), analytical electron microscopy (AEM) and electron energy loss spectroscopy (EELS). The XRD showed the presence of two populations of micas: pure $\mathrm{K}$ micas with $d_{001}=9.98 \AA$ and ammonium-bearing micas with larger $d_{001}$ values $(10.08 \AA$ and $10.05 \AA)$. The latter values indicate $\mathrm{NH}_{4}$ contents between 13 and $29 \%$ in the interlayer, which was confirmed by IR. Interstratifications of smectite and mica layers in the mica packets were not detected by XRD and TEM. Mica packets with sizes ranging from 100 to $250 \AA$ show disordered polytypes and (001) lattice fringes that reflect the presence of $\mathrm{K}$ - and $\mathrm{NH}_{4}$-bearing layers (9.9-10.2 $\AA$ ).

The combination of AEM and EELS analyses on powdered and lamellar samples indicates that micas have typical dioctahedral compositions with highly variable $\mathrm{K}$ contents. This variation in $\mathrm{K}$ is consistent with the presence of $\mathrm{K}$ and $\mathrm{NH}_{4}$ in the interlayers, even though the $\mathrm{NH}_{4}$ and $\mathrm{K}$ are not distributed homogeneously; rather they are segregated in nm-sized domains in the mica interlayer.
\end{abstract}

KEYwords: Ammonium-bearing micas, EELS, TEM, very low-grade metamorphism, XRD.

White micas are the most abundant phyllosilicates in sedimentary and very low-grade metamorphic environments, muscovite and illite with $\mathrm{K}$ as the interlayer cation being the most common members of this group. The occurrence of $\mathrm{NH}_{4}$ micas and $\mathrm{NH}_{4}$ illites with ammonium substituting for $\mathrm{K}$ in interlayer sites in nature has also been described (e.g. Duit et al., 1986; Juster et al., 1987; Daniels \& Altaner, 1990; Wilson

This paper was presented during session GG01-01: 'Clays in faults and fractures' during the 2017 International Clay Conference

*E-mail: bauluz@unizar.es

https://doi.org/10.1180/clm.2018.8 et al., 1992; Guidotti \& Sassi, 1998; Nieto, 2002; Bauluz \& Subias, 2010; Bobos, 2012).

The presence of $\mathrm{NH}_{4}$-micas was first noted by Yamamoto (1967) in some pyrophyllite schists and then by Kozac et al. (1977) in metamorphic rocks associated with aluminium hydroxides and mullite. The $\mathrm{NH}_{4}$-dominant mica was later described as a new mineral, tobelite (Higashi, 1982).

In very low-grade metapelites, tobelite is associated with organic-rich environments. Tobelite originates from the release of $\mathrm{NH}_{4}$ from organic matter, migration associated with oil, and then incorporation in phyllosilicates, with a maximum fixation coincident with the "oil window" (Williams et al., 1989, 1992). Šuchá et al. (1994) observed $\mathrm{NH}_{4}$-rich illite, along with $\mathrm{K}$ and $\mathrm{Na}$-illite, in shales associated with meta-anthracite 
coalfields in the Western Carpathians and estimated a temperature of formation of $200-270^{\circ} \mathrm{C}$ from vitrinite reflectance. In the very low-grade metamorphic rocks of Pennsylvania, Juster et al. (1987) identified minor amounts of mixed-layer $\mathrm{NH}_{4} / \mathrm{K}$, although the majority of the micas studied were discrete $\mathrm{NH}_{4}{ }^{-}$or K-illites.

In contrast to the lower-temperature cases reported (Juster et al., 1987; Drits et al., 1997), Nieto (2002) observed $\mathrm{NH}_{4}$ and $\mathrm{K}$ areas being segregated into well separated mica packets with only minor intergrowths and almost no interlayering. Thus, the evolution of tobelite during low-grade metamorphism follows a path of metastable mixed compositions which increase in terms of segregation as the grade increases.

In the present study, the improved spatial and analytical resolution of new techniques of electron microscopy were utilized to analyse the micro- and nano-texture and composition of co-existing ammonium-bearing and pure- $\mathrm{K}$ micas in very low-grade metamorphism black shales. The XRD, IR, highresolution TEM (HRTEM), AEM and EELS were used to assess the possible existence of a solid solution, interlayering or intergrowths between K- and tobelitic components in very low-grade metamorphism micas as well as their spatial relationships at the nanoscale.

\section{MATERIALS AND METHODS}

The black shales selected for the present study came from Silurian outcrops in the Iberian Range (NE Spain). In some of these outcrops the black shales were intruded by andesitic sills that produced hydrothermal alteration with crystallization of pyrophyllite $(T=224$ $\left.270^{\circ} \mathrm{C}\right)$ and later mixed-layer I-S R1 $\left(T<200^{\circ} \mathrm{C}\right)$ (Bauluz \& Subías, 2010). Subsequently, during the late Variscan, the shales and sills were folded and penetrative schistosity was developed. The overall mineralogical composition of these black shales, including the two parageneses, includes mainly pyrophyllite, $\mathrm{NH}_{4}$ - and $\mathrm{K}$-illite, mixed-layer I-S R1, quartz and minor paragonite (Bauluz \& Subías, 2010). One of the samples analysed in the present work corresponds to these shales (Checa-7). Black shales located farther from the intruded sills (sample ON-1) have a simpler mineralogy, being characterized by $\mathrm{NH}_{4}{ }^{-}$and $\mathrm{K}$-illite and quartz. In addition to their different mineralogy, according to previous XRD data, the two shales selected show $\mathrm{NH}_{4}$-rich micas with different proportions of $\mathrm{NH}_{4}$ in the mica interlayer. The typical anchizonal texture of the Silurian black shales is shown in Fig. 1. Kübler Index (KI) values ranging

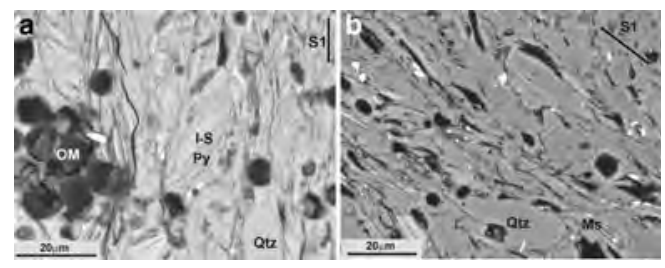

Fig. 1. Representative back-scattered SEM images showing the anchizonal textures of the black shales corresponding (a) to areas with intruded sills (modified from Bauluz \& Subías, 2010) and (b) to areas far away from the intruded sills. I-S: mixed-layered illite-smectite, Ms: muscovite, $\mathrm{OM}=$ organic matter, Py: pyrophyllite, Qtz: quartz.

from 0.24 to $0.44^{\circ} 2 \theta$ and an average of $0.34^{\circ} 2 \theta$ characteristic of low anchizone grade were noted by Bauluz \& Subías (2010).

$\mathrm{X}$-ray diffraction studies were carried out on randomly oriented powder mounts and oriented $<2 \mu \mathrm{m}$ fractions separated by centrifugation. Airdried and ethylene-glycol oriented samples were analysed to detect any expandable components. A Philips P1729 diffractometer (sample Checa-7) and an X'Pert Pro diffractometer equipped with an $\mathrm{X}^{\prime}$ Celerator solid-state linear detector (sample ON-1), with $\mathrm{Cu}-\mathrm{K \alpha}$ radiation in both cases were used. In sample $\mathrm{ON}-1$, which has superimposed peaks, the identification of phases and the measurement of $d$ spacing of each individual peak were carried out using decomposition routines included in the MacDiff software (Petschick, 2010). Quartz was used as internal standard for calibration of the $d$ spacings.

Additionally, the $<2 \mu \mathrm{m}$ fractions of sample ON-1 were saturated with $\mathrm{Mg}, \mathrm{Ca}, \mathrm{Sr}$ and $\mathrm{Na}$ by dispersion of the solid in $1 \mathrm{M}$ chloride solutions of each cation to verify if they contained smectite or vermiculite layers. These treatments were repeated twice. The solids were then washed with chloride solutions of decreasing concentration $(0.1$ and $0.01 \mathrm{M})$ and, finally, were rinsed four times with Milli-Q water to eliminate any possible remaining chlorides. Fourier-transform Infrared (FTIR) spectra were obtained using a JASCO 6200A spectrophotometer with an Attenuated Total Reflection (ATR) accessory at the Centro de Instrumentación Científica (C.I.C.), University of Granada, Spain, over the range $4000-400 \mathrm{~cm}^{-1}$ using wafers with $2.0 \mathrm{mg}$ of the $<2 \mu \mathrm{m}$ fraction and $200 \mathrm{mg}$ of $\mathrm{KBr}$ in the two selected samples.

Sample preparation for TEM study involved impregnation of the samples in L.R. White resin 
(Kim et al., 1995; Bauluz et al., 2000; Vazquez et al., 2016), to avoid collapse of expandable interlayers under high vacuum, which would make it impossible to distinguish smectite and illite layers in I-S.

Low-magnification and high-resolution (HR) TEM images were obtained using a JEOL-2000 FXII microscope equipped with an Oxford instrument detector (EDS) at the University of Zaragoza, Spain, operating at $200 \mathrm{kV}$, with a beam current of $20 \mathrm{~mA}$, using sticky wax-backed thin sections. Typical areas were removed for TEM observation via attached $\mathrm{Cu}$ washers, thinned in an ion mill, and finally coated in carbon. In order to obtain the imaging conditions described by Guthrie \& Veblen (1989, 1990a, b), through-focus series of images were obtained from $1000 \AA$ underfocus (approximate Scherzer defocus) to $1000 \AA$ overfocus, in part to obtain optimal contrast in I-S ordering (overfocus). The mixed layer I-S observed by TEM was named according to the nomenclature proposed by Bauluz et al. (2000), using the notation where $n$ is the number of illite-like layers associated with a given smectite-like layer (i.e. IS-IS- layers are denoted as I1 units, ISI-ISI- as I2 units).

The scanning transmission electron microscopy (STEM) study was performed with an Analytical Titan Low-base FEI with a beam current of $1 \mathrm{nA}$, operating at $200 \mathrm{kV}$. Previously, some EELS spectra were taken of clay particles of both samples. Because the $\mathrm{N}$ peak was only observed in mica particles of Checa-7, the rest of the EELS study was performed on this sample. Lamellae were extracted from the Checa-7 impregnated with LR White resin using a Dual Beam Helios 650 model with a Focused Ion Beam (FIB) column. The lamellae obtained were $\sim 3.5 \mu \mathrm{m} \times 3 \mu \mathrm{m}$ and $\sim 50-80 \mathrm{~nm}$ thick. Working under STEM conditions, AEM analysis was performed and EELS spectra were collected on nm-sized rectangular areas. For EELS experiments, the microscope was fitted with a Gatan Energy Filter Tridiem 866 ERS and a monochromator. The EELS spectroscopy allows detection of light elements such as nitrogen, which is not detectable by AEM, and the detection limit for this element using this method is $1 \%$.

Powdered samples of the original ON-1 specimen and those treated with $\mathrm{Sr}$ were deposited on holey, Ccoated $\mathrm{Cu}$ grids. A Philips CM20 instrument, operating at $200 \mathrm{kV}$, was used for quantitative chemical analyses in STEM mode, with an EDAX solid-state energy dispersive X-ray (EDX) detector; a scan window of $\sim 20 \mathrm{~nm} \times 100 \mathrm{~nm}$ was used for the analysis of individual clay particles. Loss of alkalis, especially $\mathrm{K}$, is a significant problem in the analysis of defect-rich minerals and short counting times were used as a compromise for K analyses (Nieto et al., 1996). Albite, biotite, muscovite, spessartine, olivine and titanite standards were used to obtain K-factors for the transformation of intensity ratios to concentration ratios according to Cliff \& Lorimer (1975). The AEM analyses of micas were normalized to six cations in tetrahedral and octahedral sites to minimize the effect on the calculated formula of the lack of data on $\mathrm{NH}_{4}$ which is not detectable by AEM. The data are expressed as atoms per formula unit (a.p.f.u.) in relation to $\mathrm{O}_{10}(\mathrm{OH})_{2}$.

The analyses by XRD, IR and HRTEM were performed on both selected samples. The STEM

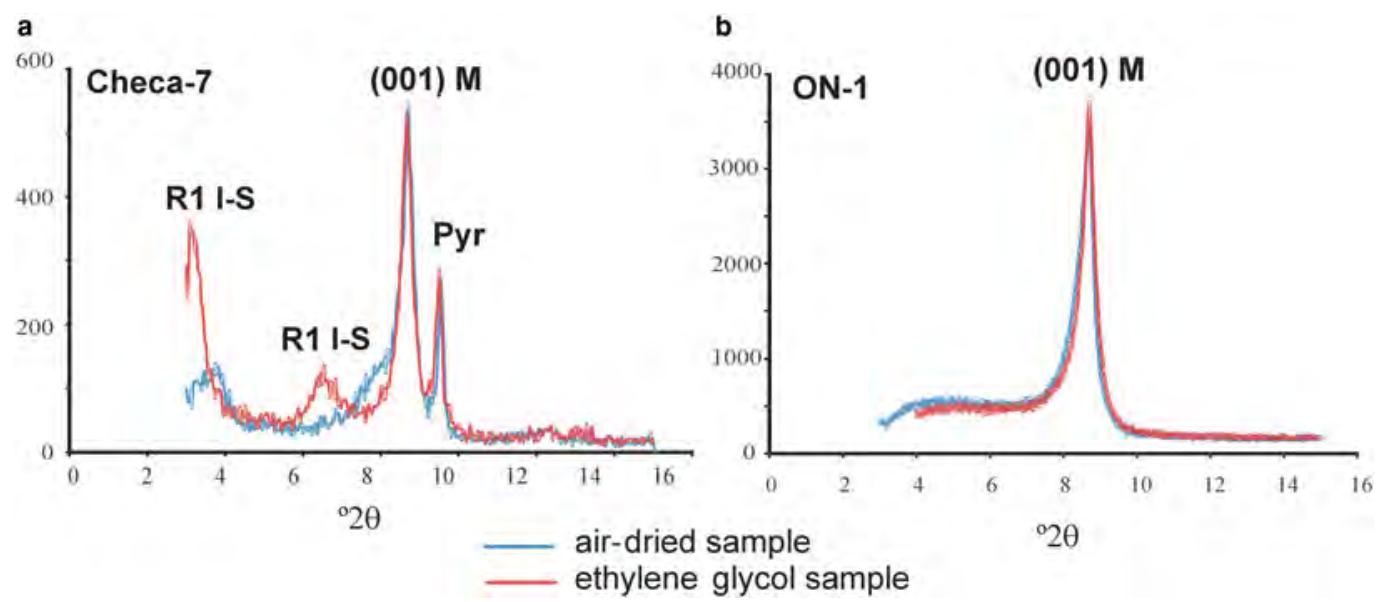

FIG. 2. XRD traces of oriented $<2 \mu \mathrm{m}$ fractions of Checa-7 (left) and ON-1 (right). R1 I-S: mixed-layer illite-smectite, M: mica, Pyr: pyrophyllite. 
study of lamellae was carried out on Checa-7, which is richer in $\mathrm{NH}_{4}$ than sample $\mathrm{ON}-1$, according to the XRD study. Microanalyses of particles of sample ON-1 were performed to prevent misinterpretation of the data, because it contains only mica phyllosilicates, unlike Checa-7, which also contains I-S and pyrophyllite.

\section{RESULTS}

\section{$X$-ray diffraction}

The oriented XRD traces of the $<2 \mu \mathrm{m}$ fraction of the two samples are shown in Fig. 2. In sample ON-1, the only peak present in the low ${ }^{\circ} 2 \theta$ region is the $(001)$ basal reflection of mica $(\sim 10.15 \AA)$; the XRD trace of
Checa-7 contains the (001) reflection of mica $(\sim 10.10 \AA)$ along with that of the pyrophyllite $(\sim 9.21 \AA)$ and those corresponding to R1 I-S $(\sim 22.79 \AA$ and $\sim 11.16 \AA)$. After ethylene glycol treatment, the mica peak shows no significant changes; in contrast the peaks of R1 I-S shift to lower angles ( $\sim 26.69 \AA$ and $\sim 13.27 \AA$, respectively) due to the presence of an expandable component. Saturation of the $\mathrm{ON}-1$ sample with $\mathrm{Mg}, \mathrm{Ca}, \mathrm{Sr}$ and $\mathrm{Na}$ caused no changes in the $d$ spacings, widths or shapes of mica peaks in the XRD patterns, indicating that the micas do not contain expandable components.

The positions of the 003 and 005 reflections of micas allowed calculation of the exact $d_{001}$ spacing, $10.08 \AA$, for sample Checa-7 and $10.05 \AA$ for
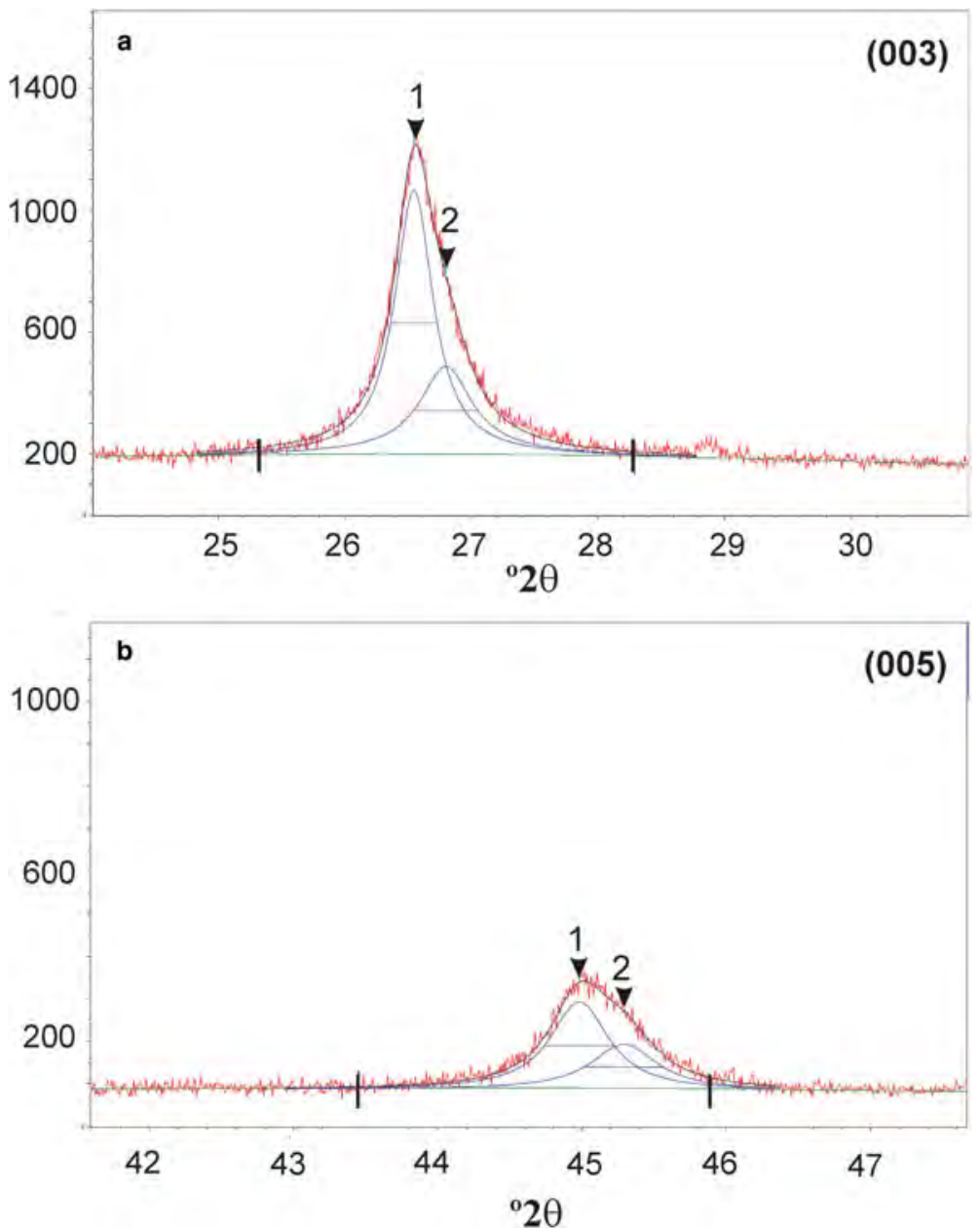

FIG. 3. XRD traces of sample ON1 and decomposition of 003 (a) and 005 (b) reflections of mica: (1) ammonium-bearing mica peak; and (2) potassium mica peak. 
sample ON-1. The decompositions of the 003 and 005 reflections are shown in Fig. 3 (which are different for Checa-7), were necessary to determine these parameters for sample ON-1. The $d_{001}$ spacing of K-illite was 9.9-10.0 $\AA$ and that of tobelite was $10.3 \AA$.
Appplication of the equations of Higashi (2000) to the $d_{001}$ spacing of $\mathrm{NH}_{4}$-bearing micas in samples ON-1 (10.05 $\AA)$ and Checa-7 (10.08 $\AA$ ) yielded 13\% and $21 \%$ of ammonium in their corresponding interlayers, whereas using the equations of Drits
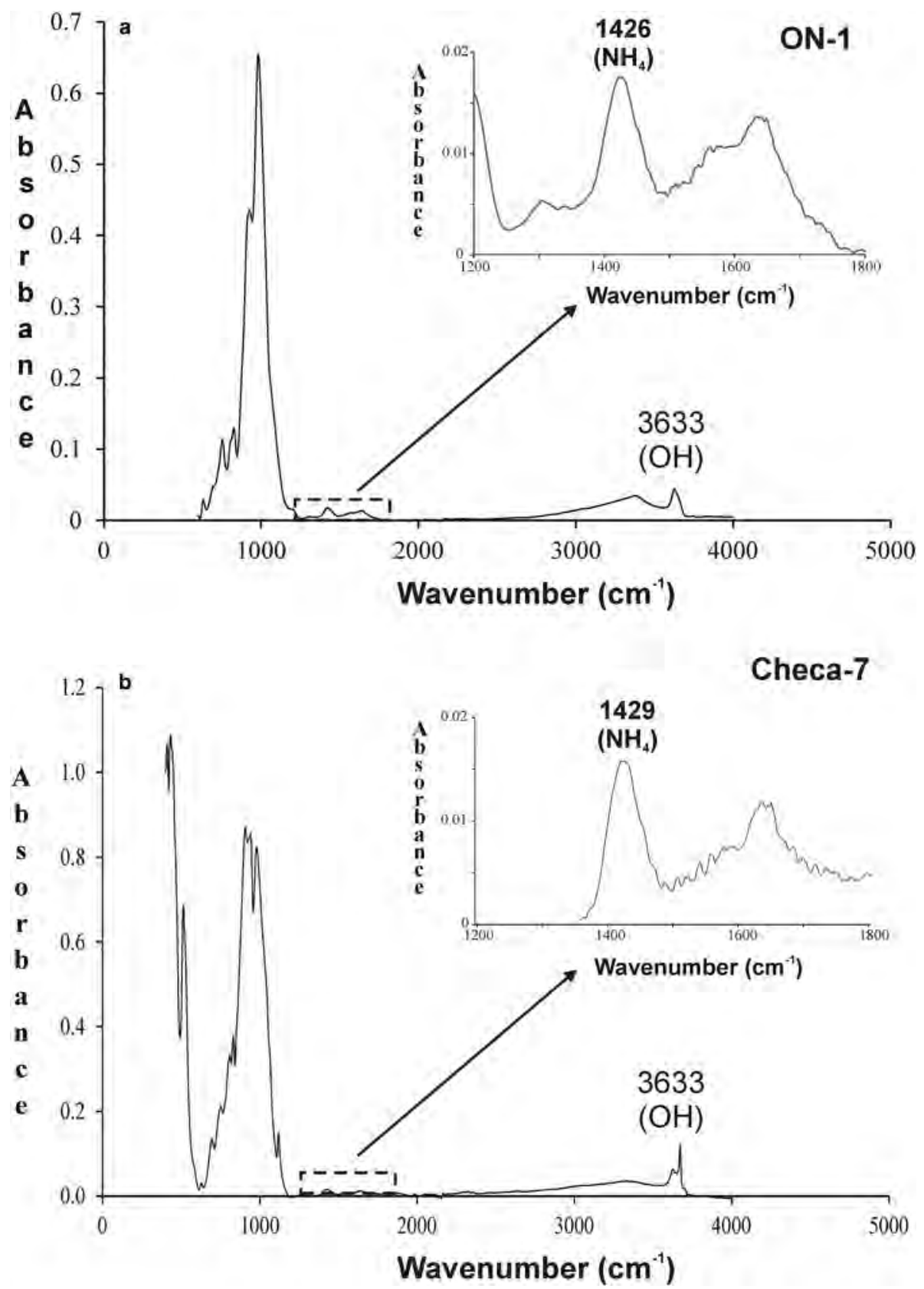

FIG. 4. IR spectra (samples ON-1 and Checa-7) showing the characteristic absorption band of $\mathrm{NH}_{4}$ in the mica interlayer. 
et al., (1997) yielded $20 \%$ and $29 \% \mathrm{NH}_{4}$, respectively. These values imply the presence of $0.13-0.20$ atoms per formula unit (a.p.f.u) of $\mathrm{NH}_{4}$ in the mica interlayer in $\mathrm{ON}-1$ and $0.21-0.29$ a.p.f.u in that of Checa-7.
Repetition of the procedure after the subtraction of $\mathrm{K}_{2}$ produced no change, as the difference in angular position between the two $\mathrm{K} \alpha$ radiations is much smaller than that between the peaks of the two micas.
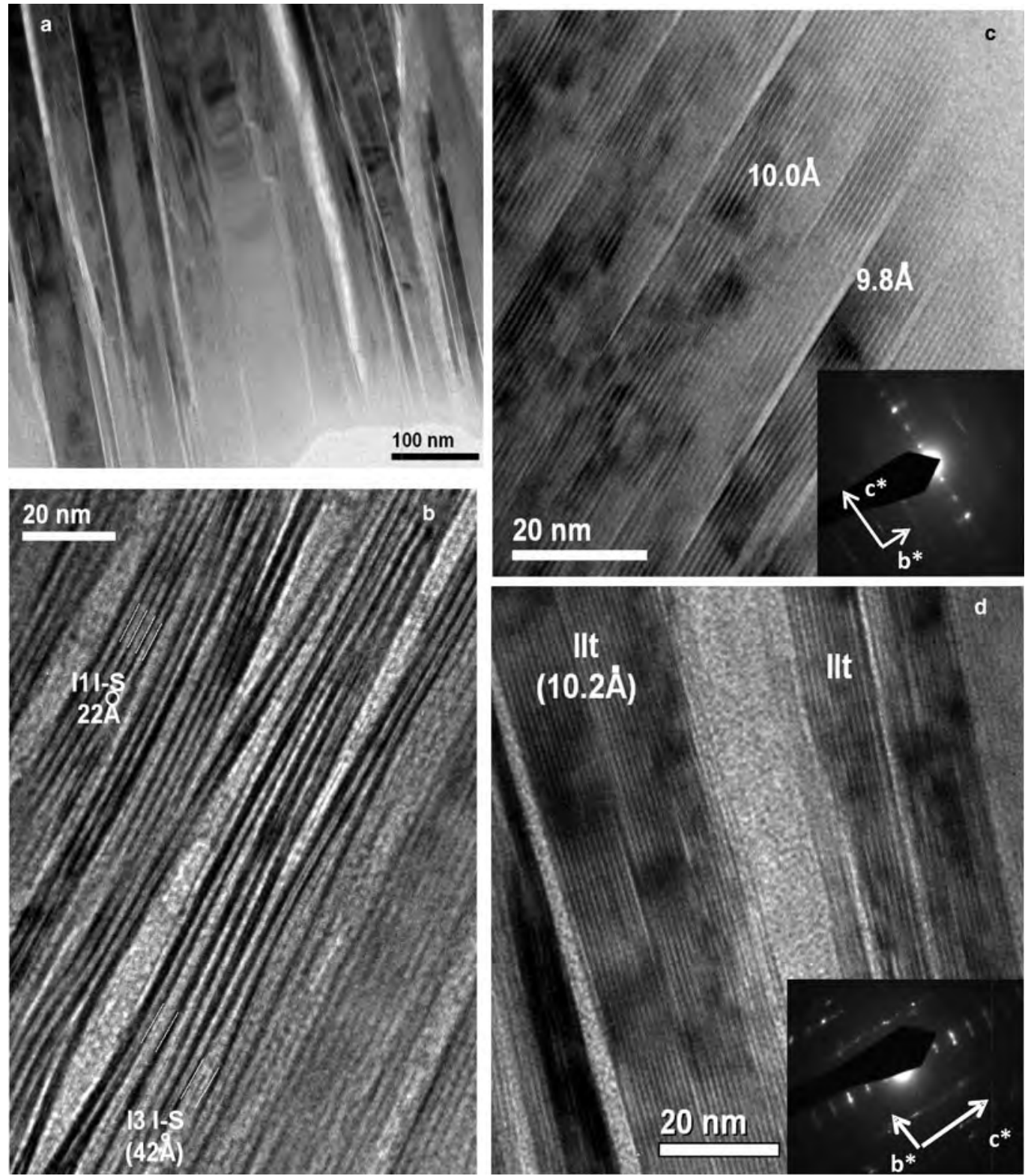

FIG. 5. Representative TEM images of sample Checa-7. (a) Low-magnification image showing subparallel to parallel phyllosilicate packets; (b) mixed-layer I-S area showing the typical contrast and spacings of I1 (22 A) and I3 units (42 A); (c, d) mica packets that, on average, show 9.8, 10 and $10.2 \AA$ lattice fringes. The corresponding insets show typical SAED patterns of $1 M d$ polytypes. 


\section{Infrared spectroscopy (IR)}

A characteristic absorption band at $\sim 1426 \mathrm{~cm}^{-1}$ is evident in the IR spectra in both samples, indicating the presence of $\mathrm{NH}_{4}$ in the mica interlayer (Fig. 4), in accordance with the XRD results. The $\mathrm{NH}_{4}$ content in sample $\mathrm{ON}-1$ was calculated, using the relative intensities of $\mathrm{NH}_{4}\left(1430 \mathrm{~cm}^{-1}\right)$ and $\mathrm{OH}^{-}\left(3620 \mathrm{~cm}^{-1}\right)$ absorption bands (Higashi, 2000). As the $\mathrm{OH}^{-}$band is common in all the phyllosilicates, application of the approach to the Checa-7 sample was precluded by the presence of pyrophyllite and R1 I-S. Application of the equation of Higashi (2000) to sample ON-1 (0.41) suggests 0.27 a.p.f.u. of $\mathrm{NH}_{4}$ in the mica interlayer.

\section{Transmission electron microscopy (TEM) study}

Representative low-magnification images of the general texture of the black shales analysed are shown in Figs 5 and 6. The areas formed by phyllosilicates are composed of parallel to sub-parallel mica packets $100-250 \AA$ long. In the case of sample Checa-7 the mica packets are separated by other packets composed of mixed-layer I-S.

Representative HRTEM images of sample Checa7 are shown in Fig. 5. The shale is composed of mica packets with nearly straight lattice fringes, constant $10 \AA$ spacings and relatively well defined boundaries typical of K-micas. Packets with spacings of 9.8 or $10.2 \AA$, on average, have also been observed. Their corresponding selected area electron diffraction (SAED) patterns are consistent with those of typical $1 M d$ polytypism. Fringes in mixed-layer I-S areas show alternate dark and light contrast typical of interstratified I-S (Guthrie \& Veblen, 1989, 1990a,b; Veblen et al., 1990). These fringes have spacings with 21-22 A periodicity (I1 units as described above) characteristic of the sum of illite-like and partially collapsed smectite-like layer spacings in R1 I-S (Kim et al., 1995; Dong et al., 1997; Bauluz et al., 2000; Vazquez et al., 2016). Occasionally, lateral transitions between I1 I-S and I3 I-S units were observed.

The coexistence of $\mathrm{K}$ micas and $\mathrm{NH}_{4}$-bearing micas was observed in sample ON-1. Packets with $10 \AA$ spacings typical of pure $\mathrm{K}$ micas and other packets with larger $d_{001}$ spacings, $10.2-10.4 \AA$ on average, corresponding to $\mathrm{NH}_{4}$ micas have been observed (Fig. 6b,c). The SAED patterns of these areas (Fig. 6d) which correspond to the $1 M d$ polytype, show splits in the 001 reflections. No differential behaviour in terms of
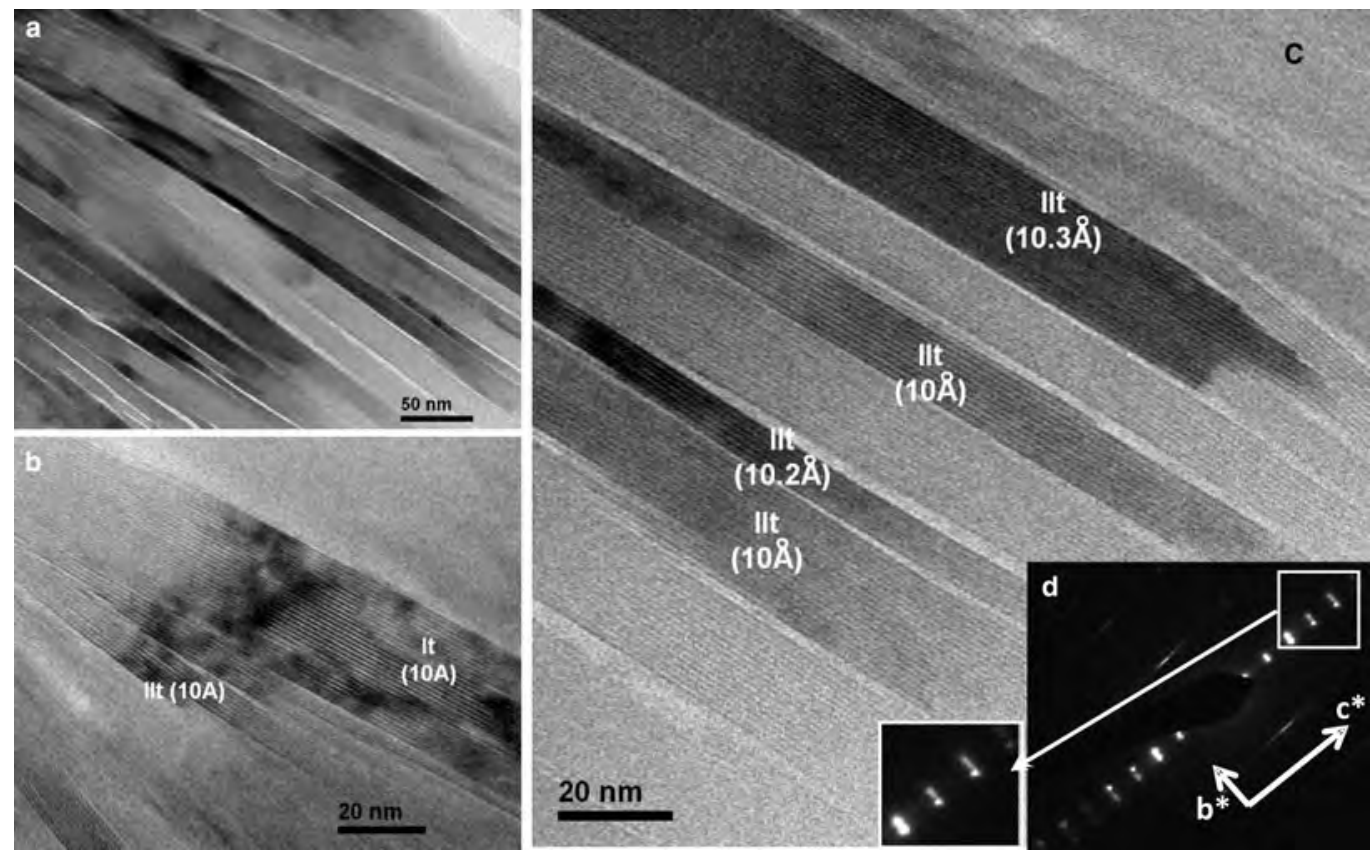

FIG. 6. Representative TEM images of sample ON-1: (a) low-magnification image showing subparallel to parallel mica packets; (b, c) mica packets formed, on average, by 10-10.3 $\AA$ fringes; (d) SAED pattern characteristic of $1 M d$ polytype; 001 reflections show a split from the 004 reflection that may correspond to potassium- and ammonium-bearing micas. 
stability under the electron beam was detected between the two types of micas.

\section{Analytical electron microscopy (AEM)}

The structural formulae of micas obtained by AEM on powdered portions of the original and Sr-treated ON-1 are listed in Table 1. The analyses indicate dioctahedral phases with $\mathrm{Al}^{\mathrm{VI}}>\mathrm{Al}^{\mathrm{IV}}$ consisting mainly of $\mathrm{Si}, \mathrm{Al}$ and $\mathrm{K}$ with minor proportions of $\mathrm{Fe}$ and $\mathrm{Mg}$. Sr was not detected in the Sr-treated sample.

Projection of mica compositions onto a $\mathrm{Si} v s$. $\mathrm{K}$ graph shows some scattering of the chemical composition of micas (Fig. 7). This is attributed, in part, to the analytical technique, but might also indicate a lack of chemical homogeneity, which is common in very low-grade metapelites. The variations in the $\mathrm{K}$ content are probably due to the variable $\mathrm{NH}_{4}$ occupancy in the mica interlayers. No significant differences were found between the AEM analyses of the Sr-treated particles and those without treatment, confirming that the micas do not contain expandable components, in agreement with the XRD results.

Dark field images (STEM) taken on lamellae that maintain the original texture of the shales show variable grey contrast along mica packets, suggesting that they do not have homogeneous compositions (Fig. 8a,b). The combination of AEM and EELS to analyse mica compositions allows us to confirm compositional variations in mica packets at the nanometer scale (Fig. 8c). The AEM analyses on $15 \mathrm{~nm} \times 25 \mathrm{~nm}$ areas yielded variable $\mathrm{K}$ contents (0.08-0.64 K a.p.f.u) in the same packet. Some of the EELS spectra acquired show a weak $\mathrm{N}$ peak in the areas with low $\mathrm{K}$ contents; the presence of $\mathrm{N}$ in area number 5 in which the $\mathrm{K}$ content is $0.08 \mathrm{~K}$ a.p.f.u. is shown in Fig. 8. Nitrogen was always detected along with $\mathrm{K}$.

TABLE 1. Structural formulae (a.p.f.u) of micas determined by AEM.

\begin{tabular}{lllllll}
\hline $\mathrm{N}$ & $\mathrm{Si}$ & $\mathrm{Al}^{\mathrm{IV}}$ & $\mathrm{Al}^{\mathrm{VI}}$ & $\mathrm{Mg}$ & $\mathrm{Fe}$ & $\mathrm{K}$ \\
\hline 1 & 3.32 & 0.68 & 1.84 & 0.11 & 0.05 & 0.69 \\
3 & 3.57 & 0.43 & 1.93 & 0.00 & 0.07 & 0.67 \\
4 & 3.35 & 0.65 & 1.97 & 0.03 & 0.00 & 0.52 \\
5 & 3.43 & 0.57 & 1.91 & 0.00 & 0.09 & 0.94 \\
6 & 3.24 & 0.76 & 1.91 & 0.04 & 0.05 & 0.78 \\
7 & 3.56 & 0.44 & 2.00 & 0.00 & 0.00 & 0.96 \\
9 & 3.45 & 0.55 & 1.88 & 0.00 & 0.12 & 0.71 \\
12 & 3.19 & 0.81 & 1.63 & 0.09 & 0.28 & 0.69 \\
13 & 3.32 & 0.68 & 1.70 & 0.18 & 0.12 & 0.68 \\
14 & 3.29 & 0.71 & 1.82 & 0.00 & 0.18 & 0.86 \\
15 & 3.40 & 0.60 & 1.84 & 0.07 & 0.09 & 0.77 \\
16 & 3.18 & 0.82 & 1.89 & 0.11 & 0.00 & 0.70 \\
18 & 3.22 & 0.78 & 1.86 & 0.04 & 0.11 & 0.92 \\
19 & 3.32 & 0.68 & 1.79 & 0.12 & 0.09 & 0.76 \\
20 & 3.49 & 0.51 & 1.66 & 0.11 & 0.23 & 0.92 \\
21 & 3.32 & 0.68 & 1.75 & 0.11 & 0.14 & 0.84 \\
22 & 3.24 & 0.76 & 1.54 & 0.21 & 0.25 & 0.81 \\
23 & 3.33 & 0.67 & 1.82 & 0.05 & 0.13 & 0.92 \\
24 & 3.30 & 0.70 & 1.88 & 0.07 & 0.05 & 0.82 \\
$1 \mathrm{~b}$ & 3.29 & 0.71 & 1.96 & 0.00 & 0.04 & 0.94 \\
$2 \mathrm{~b}$ & 3.06 & 0.94 & 1.89 & 0.11 & 0.00 & 0.99 \\
$3 \mathrm{~b}$ & 3.18 & 0.82 & 1.91 & 0.09 & 0.00 & 0.65 \\
$5 \mathrm{~b}$ & 3.38 & 0.62 & 1.93 & 0.05 & 0.02 & 0.71 \\
$7 \mathrm{~b}$ & 3.20 & 0.80 & 1.61 & 0.05 & 0.33 & 0.67 \\
$9 \mathrm{~b}$ & 3.23 & 0.77 & 1.89 & 0.05 & 0.05 & 0.92 \\
\hline & & & & & \\
\hline
\end{tabular}

Note: Normalized to six cations in tetrahedral and octahedral sites. Analyses $1 \mathrm{~b}$ to $9 \mathrm{~b}$ correspond to the Sr-saturated sample. 


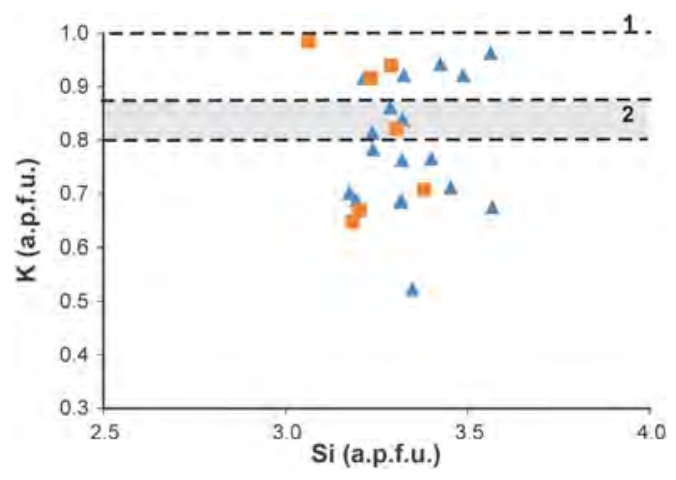

FIG. 7. Si vs. K graph showing AEM compositions of micas on single particles of sample $\mathrm{ON}-1$ ). Triangles: original sample, squares: Sr-saturated sample. Line 1 corresponds to $\mathrm{K}$ content in pure $\mathrm{K}$ micas $\left(d_{001}=9.99 \AA\right)$ and zone 2 corresponds to $\mathrm{K}$ range in ammonium-bearing micas $\left(d_{001}>10 \AA\right)$ to compositions calculated from the two decomposed peaks in the mica 005 reflection (see Fig. 3) using the equations of Higashi (2000) and Drits et al. (1997). Formulae were calculated on the basis of six tetrahedral + octahedral cations.

\section{DISCUSSION}

\section{Conditions of formation}

The black shales in the present study have similar textural characteristics and mineral paragenesis to other tobelitic shales (Juster et al., 1987; Daniels \& Altaner, 1990; Ward \& Christie, 1994; Šuchá et al., 1994), except for the organic-matter content. It is assumed, therefore, that these rocks were formed by the generally accepted process in which $\mathrm{NH}_{4}$ comes from the thermal maturation of organic matter and subsequent migration of $\mathrm{N}_{2}$ present in the pelitic rock itself. The presence of mixed-layer I-S in sample Checa-7 is associated with a low-temperature hydrothermal alteration as suggested by Bauluz \& Subias (2010); its complete absence from sample ON-1, which shows textural and chemical characteristics similar to the $\mathrm{NH}_{4}$-micas, suggests that the mixed-layer I-S is not related to the origin of the latter.

\section{Ammonium contents}

The combined use of XRD and IR confirmed the presence of micas with $\mathrm{NH}_{4}$ in their interlayers in the black shales analysed. Although the XRD patterns do not show a composite 001 mica reflection, the calculated $d_{001}$ spacings (from 003 and 005 reflections) suggest the presence of ammonium-bearing micas and pure $\mathrm{K}$ micas in both samples. The $\mathrm{NH}_{4}$ content deduced from the $d_{001}$ spacing depends on the equation used. According to the equation of Higashi (2000) the $\mathrm{NH}_{4}$ content in the interlayer space of $\mathrm{ON}-1$ and Checa-7 is 0.13 a.p.f.u. and 0.21 a.p.f.u. respectively, whereas according to the equation of Drits et al. (1997) the $\mathrm{NH}_{4}$ contents are 0.20 and 0.29 a.p.f.u., respectively. The IR spectrum of sample ON-1 yielded an $\mathrm{NH}_{4}$ occupancy of 0.27 a.p.f.u., suggesting that the $\mathrm{XRD}$ and IR methods are useful for detecting the presence of ammonium in mica interlayers and for giving an approach to the mean value of each sample. Differences in the $\mathrm{NH}_{4}$ content obtained from XRD and IR are probably due to the influence of other chemical variables on the $d_{001}$ spacing (Guidotti et al., 1992; Nieto, 2002), and/or to the mixing effect of pure $\mathrm{K}$ micas on the IR data.

The HRTEM images show that both black shales have similar textures and similar ranges in size of the mica packets typical of an anchizonal grade. The TEM images also display the coexistence of $\sim 10 \AA$ layer packets and 10.2-10.3 $\AA$ layer packets suggesting the presence of ammonium interlayers, which in places, may produce some splits in 001 reflections in the SAED pattern. Stacking in mica is always characteristic of disordered polytypes $\left(1 M_{d}\right)$. Finally, intergrowths among mica and I-S packets have been observed in Checa-7. However, the typical contrast of mixed-layer I-S in the mica crystals was not observed either in Checa-1 or in ON-1.

The K content of individual particles analysed in situ by AEM is shown in Fig. 7. These analyses contain indirect data on the $\mathrm{NH}_{4}$ content of various particles and show a significant scattering of data between $0.5-0.6$ and $1.0 \mathrm{~K}$ a.p.f.u. This scattering is due to: (1) real differences in the $\mathrm{NH}_{4}$ content among individual packets, as was demonstrated by various spacings in the HRTEM images (Figs 5, 6) and differences in terms of contrast in dark field STEM images (Fig. 8a), produced by variable K contents (Fig. 8b); (2) mixing of the particles analysed of variable proportions of packets having lesser or greater $\mathrm{K}$ contents; (3) analytical uncertainty, which is expected to be significant, due in part to $\mathrm{K}$ loss during analysis. The $\mathrm{K}$ content varies continuously between 0.6 and 1 a.p.f.u., in apparent contradiction with the XRD results, which predict the existence of two populations of packets, $\mathrm{NH}_{4}$-free $\left(d_{001}=9.98 \AA\right)$ and $\mathrm{NH}_{4}$-bearing $\left(d_{001}=10.05 \AA\right)$. Nevertheless, reasons 2 and 3 would produce a significant scattering of the data corresponding to each population precluding the distinction of the two populations based on the AEM data of the particles. 

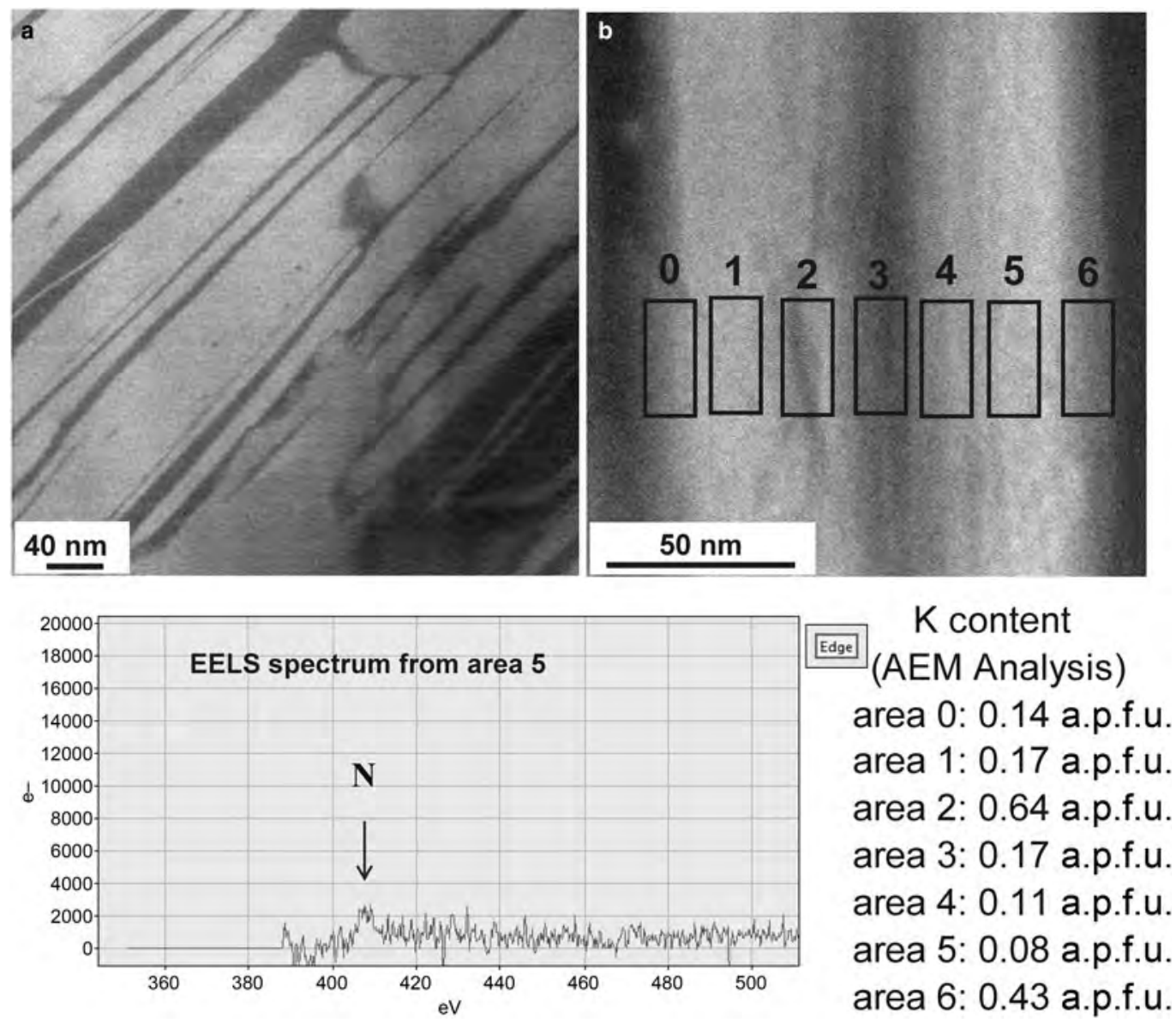

FIG. 8. (a) Representative dark field image of a lamella in sample Checa-7. (b) Areas analysed on the lamella by EELS and AEM. (c) EELS spectrum showing a $\mathrm{N}$ peak from area number 5 and $\mathrm{K}$ contents (a.p.f.u.) detected by AEM on the analysed areas. Formulae were calculated on the basis of six tetrahedral + octahedral cations.

\section{Mica compositions}

The composition of the micas analysed varies between crystals, but lies within the usual range of dioctahedral micas. Although some of this variability might be due to the AEM method, the heterogeneity in the chemical composition of minerals formed during diagenesis and very low-grade metamorphism is a well known fact (e.g. Li et al., 1994; Merriman et al., 1995; Dalla Torre et al.; 1996; Nieto et al., 1996; Livi et al., 1997; Giorgetti et al., 1997).

The variations in $\mathrm{K}$ contents might also imply variation in the $\mathrm{NH}_{4}$ content. The dark-field images and the analyses on lamellae of mica packets reflect compositional variations at the nanometer scale, suggesting the existence of K-rich domains inside the packet and, comparatively $\mathrm{NH}_{4}$-richer domains in the same crystal. The small $\mathrm{N}$ contents in the micas analysed make it difficult to detect and measure by EELS and only weak $\mathrm{N}$ peaks were detected in some EELS spectra, in areas with low $\mathrm{K}$ contents. The fact that $\mathrm{N}$ was detected along with $\mathrm{K}$ suggests that there are, apparently, no pure $\mathrm{NH}_{4}$-domains within the mica crystals. Finally, the $\mathrm{N}$ and $\mathrm{K}$ are not distributed homogeneously in mica interlayers but are segregated into nanometre domains.

The $\mathrm{K}$ contents reported here ( $\mathrm{K} \geq 0.52$ a.p.f.u.) from analyses on powdered samples, along with the XRD and IR data, suggest that there are pure K-micas, with $d_{001}=9.98 \AA$ and micas which contain $\mathrm{K}$ and $\mathrm{NH}_{4}$ in the interlayer with $d_{001} \geq 10 \AA$, but they probably have larger $\mathrm{K}$ than $\mathrm{NH}_{4}$ contents on average. However, the existence of K-rich and $\mathrm{K}$-poor domains of nanometer 
size inside the mica crystals reflects a segregation in the distribution of the $\mathrm{K}$ and $\mathrm{NH}_{4}$ in the interlayer.

Drits et al. (1997) noted that mixed-layer I-S in diagenetic shales from North Sea have differentiated $\mathrm{K}$ and $\mathrm{NH}_{4}$ end-member illite layers in the mixed-layer I-S. Nieto (2002) reported that $\mathrm{NH}_{4}$ - and $\mathrm{K}$-dominated micas in low-grade temperature conditions have been segregated into well-separated packets with scarce intergrowths and almost no mixed layers.

In the very low-grade Silurian shales of the present study, segregation domains in the same mica packet, with variable proportions of $\mathrm{K} / \mathrm{NH}_{4}$, might represent a previous, less evolved, stage than that reported by Nieto (2002) for higher-temperature environments. This path is similar to the evolution of paragonite, margarite and muscovite (Livi et al., 1997, 2008). Livi et al. (2008) reported STEM images of $(001)$ white mica planes with ordered domains of paragonite, margarite and muscovite within the basal plane; the domain boundaries may be sharp and structurally controlled or diffuse and irregular. A similar distribution model for tobelite and muscovite might occur in this study, with the mixture of domains of $\mathrm{NH}_{4}$-bearing micas and pure $\mathrm{K}$-micas producing mixed intermediate compositions, similar to the widely described $\mathrm{Na}-\mathrm{K}$ mica case. The relatively high $\mathrm{K}$ contents reported by $\mathrm{AEM}$ on powdered samples, indicate that the $\mathrm{K}$-poorer packets also have higher $\mathrm{K}$ than $\mathrm{NH}_{4}$ contents; hence they are not tobelitic but $\mathrm{NH}_{4}$-bearing muscovitic packets, in agreement with the $d_{001}$ spacings and the IR spectra.

Therefore, the Sierra de Albarracín black shales are different from previously described cases of $\mathrm{NH}_{4}$-rich micas because of the absence of the tobelitic part of the compositional gap between tobelitic and muscovitic micas, described by Nieto (2002). The compositions correspond to the muscovite part of the gap, perhaps motivated by a lower activity of the $\mathrm{NH}_{4}$ ion. Thus, the evolution of mica and tobellite during low-grade metamorphism might follow a path of metastable mixed compositions increasing in segregation with the increase of the metamorphic grade (Nieto 2002).

\section{CONCLUSIONS}

The combination of XRD, IR, TEM, AEM and EELS shows the presence of two populations of micas in the very-low grade black shales analysed from the Silurian in NE Spain. One population consists of pure $\mathrm{K}$ micas with $9.98 \AA$ basal spacing and the other of $\mathrm{NH}_{4}$ - and $\mathrm{K}$ bearing micas with basal spacings $>10 \AA$. Both types of micas show similar textures and crystal sizes characteristic of anchizone shales.
The ammonium and potassium micas have $\mathrm{NH}_{4}$ and $\mathrm{K}$ distributed heterogeneously in the interlayer, and they are segregated, forming nm-sized domains. The compositional and textural relationships between $\mathrm{NH}_{4}$ and $\mathrm{K}$ micas in the evolution of very low grade metamorphism reproduce the same trends previously described for $\mathrm{Na}, \mathrm{Ca}$ and $\mathrm{K}$ micas.

\section{ACKNOWLEDGEMENTS}

This research has been funded by the Spanish Ministerio de Economía y Competitividad (CGL2013-46169-C2-1P) and the Gobierno de Aragón and the European Social Fund (Grupo Consolidado, Recursos Minerales E45). The authors are grateful for comments and suggestions by two anonymous reviewers which significantly improved a previous version of the manuscript. The authors also acknowledge the use of the Servicio de Apoyo a la Investigación-SAI, University of Zaragoza (Spain) and the "Laboratorio de Microscopías Avanzadas" at Instituto de Nanociencia de Aragón-University of Zaragoza (Spain) for offering access to their instruments and expertise.

\section{REFERENCES}

Bauluz B. \& Subías I. (2010) Coexistence of pyrophyllite, $\mathrm{I}-\mathrm{S}, \mathrm{R} 1$ and $\mathrm{NH}_{4}^{+}$-rich illite in Silurian black shales (Sierra de Albarracín, NE Spain): metamorphic vs. hydrothermal origin. Clay Minerals, 45, 383-392.

Bauluz B., Peacor D.R. \& González-López J.M. (2000) Transmission electron microscopy study of illitization in pelites from the Iberian Range, Spain: Layer-bylayer replacement? Clays and Clay Minerals, 48, 374-384.

Bobos I. (2012) Characterization of smectite to $\mathrm{NH}_{4}$-illite conversion series in the fossil hydrothermal system of Harghita Bai, east Carpathians, Romania. American Mineralogist, 97, 962-982.

Cliff G. \& Lorimer G.W. (1975) The quantitative analysis of thin specimens. Journal of Microscopy, 103, 203-207.

Dalla-Torre M., Livi K., Veblen D.R. \& Frey M. (1996) White K-mica evolution from phengite to muscovite in shales and shale matrix melange, Diablo Range, California. Contributions to Mineralogy and Petrology, 123, 390-405.

Daniels E.J. \& Altaner S.P. (1990) Clay mineral authigenesis in coal and shale from the Anthracite region, Pennsylvania. American Mineralogist, 75, 825-839.

Dong H., Peacor D.R. \& Freed R.L. (1997) Phase relations among smectite, R1 illite-smectite, and illite. American Mineralogist, 82, 379-391.

Drits V.A., Lindgreen H. \& Salyn A.L. (1997) Determination of the content and distribution of fixed ammonium in illite-smectite by $\mathrm{X}$-ray 
diffraction: Application to North Sea illite-smectite. American Mineralogist, 82, 79-87.

Duit W., Jansen J.B.H., van Bremen A. \& Bos A. (1986) Ammonium micas in metamorphic rocks as exemplified by Dome de l'Agout (France). American Journal of Science, 286, 702-732.

Guidotti C.V. \& Sassi F.P. (1998) Miscellaneous isomorphous substitutions in Na-K white mica; a review, with special emphasis to metamorphic micas. Rendiconti Lincei Scienze Fisiche e Naturali, 9, 57-78.

Guidotti C.V., Mazzoli C., Sassi F.P. \& Blencoe J.G. (1992) Compositional controls on the cell dimensions of $2 M_{1}$ muscovite and paragonite. European Journal of Mineralogy, 4, 283-297.

Giorgetti G., Memmi I. \& Nieto F. (1997) Microstructures of intergrown phyllosilicate grains from Verrucano metasediments (Northern Apennines, Italy). Contributions to Mineralogy and Petrology, 128, 127-138.

Guthrie G.D. \& Veblen D.R. (1989) High-resolution transmission electron microscopy of mixed-layer illite/ smectite: Computer simulation. Clays and Clay Minerals, 37, 1-11.

Guthrie G.D. \& Veblen D.R. (1990a) High-resolution transmission electron microscopy applied to clay minerals. Pp. 75-93 in: Spectroscopic Characterization of Minerals and their Surfaces (L. M. Coyne, S.W.S. McKeever \& D.F. Blake, editors). Symposia Series 415, American Chemical Society, Washington, D.C.

Guthrie G.D. \& Veblen D.R. (1990b) High-resolution transmission electron microscopy of mixed-layer illite/ smectite: Computer simulations. American Mineralogist, 75, 276-288.

Higashi S. (1982) Tobelite, a new ammonium dioctahedral mica. Mineralogical Journal, 11, 138-146.

Higashi S. (2000) Ammonium-bearing mica and mica/ smectite of several pottery stone and pyrophyllite deposits in Japan: Their mineralogical properties and utilization. Applied Clay Science, 16, 171-184.

Juster T.C., Brown P.E. \& Bailey S.W. (1987) $\mathrm{NH}_{4}$ bearing illite in very low grade metamorphic rocks associated with coal, north-eastern Pennsylvania. American Mineralogist, 72, 555-565.

Kim J.W., Peacor D.R., Tessier D. \& Elsass F. (1995) A technique for maintaining texture and permanent expansion of smectite interlayers for TEM observations. Clays and Clay Minerals, 43, 51-57.

Kozac J., Ocenas D. \& Derco J. (1977) The discovery of ammonium hydromica in the Vihorlat Mountains, eastern Slovakia. Mineralia Slovaca, 9, 6, 479.

Li G.J., Peacor D.R., Merriman R.J. \& Roberts B. (1994) The diagenetic to low-grade metamorphic evolution of matrix white micas in the system muscovite-paragonite in a mudrock from Central Wales, United Kingdom. Clays and Clay Minerals, 42, 369-381.

Livi K.J.T., Veblen D.R., Ferry J.M. \& Frey M. (1997) Evolution of 2:1 layered silicates in low-grade metamorphosed Liassic shales of Central Switzerland. Journal of Metamorphic Geology, 12, 323-344.

Livi K.J.T., Christidis G.E., Arkai P. \& Veblen D.R. (2008) White mica domain formation: A model for paragonite, margarite, and muscovite formation during prograde metamorphism. American Mineralogist, 93, 520-527.

Merriman R.J., Roberts B., Peacor D.R. \& Hirons S.R. (1995) Strain-related differences in the crystal growth of white mica and chlorite: a TEM and XRD study of the development of metapelitic microfabrics in the Southern Uplands thrust terrane, Scotland. Journal of Metamorphic Geology, 13, 559-576.

Nieto F. (2002) Ammonium illite from anchimetamorphic shales associated with anthracite in the Zemplinicum of the Western Carpathians. American Mineralogist, 87, 205-216.

Nieto F., Ortega-Huertas M., Peacor D. \& Arostegui J. (1996) Evolution of illite/smectite from early diagenesis through incipient metamorphism in sediments of the Basque-Cantabrian Basin. Clays and Clay Minerals, 44, 304-323.

Petschick R. (2010) MacDiff 4.2.6. http://www.geologie.unirankfurt.de/Staff/Homepages/Petschick/Classicsoftware. html.

Šuchá V., Kraus I. \& Madejová J. (1994) Ammonium illite from anchimetamorphic shales associated with anthracite in the Zemplinicum of the Western Carpathians. Clay Minerals, 29, 369-377.

Vazquez M., Bauluz B., Nieto F. \& Morata D. (2016) Illitization sequence controlled by temperature in volcanic geothermal systems: The Tinguiririca geothermal field, Andean Cordillera, Central Chile. Applied Clay Science, 134, 221-234.

Veblen D.R., Guthrie G.D., Jr., Livi K.J.T. \& Reynolds R.C., Jr. (1990) High-resolution transmission electron microscopy and electron diffraction of mixed-layer illite/smectite: Experimental results. Clays and Clays Minerals, 38, 1-13.

Ward C.R. \& Christie P.J. (1994) Clays and other minerals in coal seams of the Moura-Baralaba area, Bowen Basin, Australia. International Journal of Coal Geology, 25, 287-309.

Williams L.B., Ferrell R.E., Chinn E.W. \& Sassen R. (1989) Fixed ammonium in clays associated with crude oils. Applied Geochemistry, 4, 605-616.

Williams L.B., Wilcoxon B.R., Ferrell R.E. \& Sassen R. (1992) Diagenesis of ammonium during hydrocarbon maturation and migration. Applied Geochemistry, 7, 123-134.

Wilson P.N., Parry W.T. \& Nash W.P. (1992) Characterization of hydrothermal tobelitic veins from black shale, Oquirrh Mountains, Utah. Clays and Clay Minerals, 40, 405-420.

Yamamoto T. (1967) Mineralogical studies of sericite associated with Roseki ores in the western part of Japan. Mineralogical Journal, 5, 77-97. 